\title{
Contents IMIA Yearbook of Medical Informatics 2021
}

\section{President's Statement \\ Obituary \\ Editorial \\ IAHSI Paper \\ WHO Paper \\ Keynote}

Special Section: Managing Pandemics with Health Informatics

Survey

Working Group Contributions
S. Koch

Leading IMIA through a Global Pandemic

S. Koch, D. Shires, D. Skiba, M. Ball, J. H. van Bemmel

Hans Peterson (1928 - 2021) - Forever in Our Hearts, Always in Our Thoughts

Health Data, Information, and Knowledge Sharing for Addressing the COVID-19

R. Haux, M. J. Ball, W. R. Hersh, E. Huesing, M. Kimura, S. Koch, F. Martin-Sanchez, P. Otero

The International Academy of Health Sciences Informatics (IAHSI): 2020 Report

S. Koch, W. R. Hersh, R. Bellazzi, T. Y. Leong, M. Yedaly, N. Al-Shorbaji

Digital Health during COVID-19: Informatics Dialogue with the World Health Organization

M. A. Basit, C. U. Lehmann, R. J. Medford

Managing Pandemics with Health Informatics: Successes and Challenges

Mapping the Role of Digital Health Technologies in Prevention and Control of COVID-19

Pandemic: Review of the Literature

S. Kobayashi, L. Falcón, H. Fraser, J. Braa, P. Amarakoon, A. Marcelo, C. Paton Using Open Source, Open Data, and Civic Technology to Address the COVID-19 Pandemic and Infodemic

S.-T. Liaw, C. Kuziemsky, R. Schreiber, J. Jonnagaddala, H. Liyanage, A. Chittalia, R. Bahniwal, J. W. He, B. L. Ryan, D. J. Lizotte, J. K. Kueper, A. L. Terry, S. de Lusignan Primary Care Informatics Response to Covid-19 Pandemic: Adaptation, Progress, and Lessons from Four Countries with High ICT Development

F. Magrabi, E. Ammenwerth, C. K. Craven, K. Cresswell, N. F. De Keizer, S. K. Medlock, P. J. Scott, Z. S.-Y. Wong, A. Georgiou

Managing Pandemic Responses with Health Informatics - Challenges for Assessing Digital Health Technologies

M. Topaz, L.-M. Peltonen, J. Mitchell, D. Alhuwail, S.-S. Barakati, A. Lewis, H. Moen, S. P. K. Veeranki, L. Block, T. Risling, C. Ronquillo How to Improve Information Technology to Support Healthcare to Address the COVID-19

Pandemic: an International Survey with Health Informatics Experts 
Synopsis B. E. Dixon, J. H. Holmes

Managing Pandemics with Health Informatics

Best Paper Selection Content summaries of:

Ahmed K, Bukhari MA, Mlanda T, Kimenyi JP, Wallace P, Okot Lukoya C, Hamblion EL, Impouma

B. Novel approach to support rapid data collection, management, and visualization during the COVID-19 outbreak response in the World Health Organization African Region: development of a data summarization and visualization tool. JMIR Public Health Surveill 2020;6(4):e20355

Garcia M, Lipskiy N, Tyson J, Watkins R, Esser ES, Kinley T. Centers for disease control and prevention 2019 novel coronavirus disease (COVID-19) information management: addressing national health-care and public health needs for standardized data definitions and codified vocabulary for data exchange. J Am Med Inform Assoc Jul 2020;27(9):1476-87

Gong M, Liu L, Sun X, Yang Y, Wang S, Zhu H. Cloud-based system for effective surveillance and control of COVID-19: useful experiences from Hubei, China. J Med Internet Res Apr 2020;22(4):e18948

Reeves JJ, Hollandsworth HM, Torriani FJ, Taplitz R, Abeles S, Tai-Seale M, Millen M, Clay BJ, Longhurst CA. Rapid response to COVID-19: health informatics support for outbreak management in an academic health system. J Am Med Inform Assoc Jun 2020;27(6):853-9

Section 1: Health Information Management

Survey

\section{B. L. Massoudi, D. Sobolevskaia}

Keep Moving Forward: Health Informatics and Information Management beyond the COVID-19 Pandemic

Synopsis M. Bloomrosen, E. S. Berner

Findings from the 2021 Yearbook Section on Health Information Management

Best Paper Selection

\section{Content summaries of:}

Cappetta K, Lago L, Potter J, Phillipson L. Under-coding of dementia and other conditions indicates scope for improved patient management: A longitudinal retrospective study of dementia patients in Australia. Health Inf Manag 2020:1833358319897928

Powell KR, Deroche CB, Alexander GL. Health data sharing in US nursing homes: a mixed methods study. J Am Med Dir Assoc 2021 May;22 (5):1052-59

Sheriffdeen A, Millar JL, Martin C, Evans M, Tikellis G, Evans SM. (Dis)concordance of comorbidity data and cancer status across administrative datasets, medical charts, and self-reports. BMC Health Serv Res 2020;20(1):858

Section 2: Human Factors and Organizational Issues

\section{Survey}

Synopsis

\section{Best Paper Selection}

\section{J. Marquard}

Human Factors and Organizational Issues in Health Informatics: Innovations and Opportunities

Human Factors and Organizational Issues Section Synopsis IMIA Yearbook 2021

\section{Content summaries of:}

Adler-Milstein J, Zhao W, Willard-Grace R, Knox M, Grumbach K. Electronic health records and burnout: Time spent on the electronic health record after hours and message volume associated with exhaustion but not with cynicism among primary care clinicians. J Am Med Inform Assoc 2020;27(4):531-8

Brewer LC, Fortuna KL, Jones C, Walker R, Hayes SN, Patten CA, Cooper LA. Back to the future: Achieving health equity through health informatics and digital health. JMIR Mhealth Uhealth 2020;8(1):e14512

Reading Turchioe M, Grossman LV, Myers AC, Baik D, Goyal P, Masterson Creber RM. Visual analogies, not graphs, increase patients' comprehension of changes in their health status. J Am Med Inform Assoc 2020;27(5):677-89 
Section 3: Clinical Information Systems

Survey

Working Group Contribution

Synopsis

Best Paper Selection

Section 4: Sensor, Signal and Imaging Informatics

Working Group Contribution

Synopsis

Best Paper Selection
Tschandl P, Rinner C, Apalla Z, Argenziano G, Codella N, Halpern A, Janda M, Lallas A, Longo C, Josep Malvehy J, Paoli J, Puig S, Rosendahl C, Soyer HP, Zalaudek I, Kittler H. Human-computer collaboration for skin cancer recognition. Nat Med 2020;26(8):1229-34

J. J. Reeves, N. M. Pageler, E. C. Wick, G. B. Melton, Y.-H. G. Tan, B. J. Clay, C. A. Longhurst The Clinical Information Systems Response to the COVID-19 Pandemic

A. Basu, C. Kuziemsky, M. de Araújo Novaes, A. Kleber, F. Sales, N. Al-Shorbaji, J. F.

Flórez-Arango, S. B. Gogia, K. Ho, I. Hunter, S. lyengar, O. John, S. John, G. Kulatunga, V. K. Rajput, P. Ranatunga, J. G. Udayasankaran

Telehealth and the COVID-19 Pandemic: International Perspectives and a Health Systems

Framework for Telehealth Implementation to Support Critical Response

W. O. Hackl, A. Hoerbst

Clinical Information Systems Research in the Pandemic Year 2020

Content summaries of:

Fabregat A, Magret M, Ferré JA, Vernet A, Guasch N, Rodríguez A, Gómez J, Bodí M. A Machine Learning decision-making tool for extubation in Intensive Care Unit patients. Comput Methods Programs Biomed 2021;200:105869

Kempa-Liehr AW, Lin CYC, Britten R, Armstrong D, Wallace J, Mordaunt D, O'Sullivan M. Healthcare pathway discovery and probabilistic machine learning. Int J Med Inform 2020;137:104087

Li Y, Nair P, Lu XH, Wen Z, Wang Y, Dehaghi AAK, Miao Y, Liu W, Ordog T, Biernacka JM, Ryu E, Olson JE, Frye MA, Liu A, Guo L, Marelli A, Ahuja Y, Davila-Velderrain J, Kellis M. Inferring multimodal latent topics from electronic health records. Nat Commun 2020;1 1 (1):2536

Weemaes M, Martens S, Cuypers L, van Elslande J, Hoet K, Welkenhuysen J, Goossens R, Wouters S, Houben E, Jeuris E, Jeuris K, Laenen L, Bruyninckx K, Beuselinck K, André E, Depypere M, Desmet S, Lagrou K, Van Ranst M, Verdonck AKLC, Goveia J. Laboratory information system requirements to manage the COVID-19 pandemic: A report from the Belgian national reference testing center. J Am Med Inform Assoc 2020;27(8):1293-9

V. Vimarlund, E. M. Borycki, A. W. Kushniruk, K. Avenberg

Ambient Assisted Living: Identifying New Challenges and Needs for Digital Technologies and

Service Innovation

W. Hsu, C. Baumgartner, T. M. Deserno

Notable Papers and New Directions in Sensors, Signals, and Imaging Informatics

Content summaries of:

Gemein LAW, Schirrmeister RT, Chrabąszcz P, Wilson D, Boedecker J, Schulze-Bonhage A, Hutter F, Ball T. Machine-learning-based diagnostics of EEG pathology. Neuroimage 2020 0ct 15;220:117021

Karimi D, Dou H, Warfield SK, Gholipour A. Deep learning with noisy labels: Exploring techniques and remedies in medical image analysis. Med Image Anal 2020 0ct;65:101759

Langner T, Strand R, Ahlström H, Kullberg J. Large-scale biometry with interpretable neural network regression on UK Biobank body MRI. Sci Rep 2020 Oct 20;10(1):17752

Saito H, Aoki T, Aoyama K, Kato Y, Tsuboi A, Yamada A, Fujishiro M, Oka S, Ishihara S, Matsuda T, Nakahori M, Tanaka S, Koike K, Tada T. Automatic detection and classification of protruding lesions in wireless capsule endoscopy images based on a deep convolutional neural network. Gastrointest Endosc 2020 Jul;92(1):144-151.el 
Section 5: Decision Support

Survey P. Taber, C. Radloff, G. Del Fiol, C. Staes, K. Kawamoto

New Standards for Clinical Decision Support: A Survey of The State of Implementation

Synopsis D. Borbolla, G. Ficheur

Clinical Decision Support Systems and Computerized Provider Order Entry: Contributions from 2020

Best Paper Selection Content summaries of:

Wu G, Yang P, Xie Y, Woodruff HC, Rao X, Guiot J, Frix AN, Louis R, Moutschen M, Li J, Li J, Yan

C, Du D, Zhao S, Ding Y, Liu B, Sun W, Albarello F, D'Abramo A, Schininà V, Nicastri E, Occhipinti M, Barisione G, Barisione E, Halilaj I, Lovinfosse P, Wang X, Wu J, Lambin P. Development of a clinical decision support system for severity risk prediction and triage of COVID-19 patients at hospital admission: an international multicentre study. Eur Respir J 2020 Aug 20;56(2):2001104

Balestrieri M, Sisti D, Rocchi M, Rucci P, Simon G, Araya R, de Girolamo G. Effectiveness of clinical decision support systems and telemedicine on outcomes of depression: a cluster randomized trial in general practice. Fam Pract 2020 Nov 28;37(6):731-7

Section 6: Knowledge Representation and Management

Survey K. Verspoor

The Evolution of Clinical Knowledge During COVID-19: Towards a Global Learning Health System

Synopsis F. Dhombres, J. Charlet

Knowledge Representation and Management: Interest in New Solutions for Ontology Curation

\section{Best Paper Selection Content summaries of:}

Le DH. UFO: A tool for unifying biomedical ontology-based semantic similarity calculation, enrichment analysis and visualization. PLOS One 2020;15(7):e0235670

Robinson PN, Ravanmehr V, Jacobsen JOB, Danis D, Zhang XA, Carmody LC, Gargano MA, Thaxton CL, Core UNCB, Karlebach G, Reese J, Holtgrewe M, Kohler S, McMurry JA, Haendel MA, Smedley D. Interpretable clinical genomics with a likelihood ratio paradigm. Am J Hum Genet 2020;107(3):403-17

Slater LT, Gkoutos GV, Hoehndorf R. Towards semantic interoperability: finding and repairing hidden contradictions in biomedical ontologies. BMC Med Inform Decis Mak 2020;20(Suppl 10):311

Zheng F, Shi J, Yang Y, Zheng WJ, Cui L. A transformation-based method for auditing the IS-A hierarchy of biomedical terminologies in the Unified Medical Language System. J Am Med Inform Assoc 2020;27(10):1568-75 
Section 7: Consumer Health Informatics

and Education

Survey T. Dingler, D. Kwasnicka, J. Wei, E. Gong, B. Oldenburg

The Use and Promise of Conversational Agents in Digital Health

\section{Working Group Contribution}

Synopsis

Best Paper Selection

Section 8: Bioinformatics and Translational Informatics

Survey

\section{S. P. McGrath, M. L. Benton, M. Tavakoli, N. P. Tatonetti}

\section{E. Gabarron, 0. Rivera-Romero, T. Miron-Shatz, R. Grainger, K. Denecke}

Role of Participatory Health Informatics in Detecting and Managing Pandemics: Literature Review

P. Staccini, A. Y. S. Lau

Consumer Informatics and COVID-19 Pandemics: Challenges and Opportunities for Research

\section{Content summaries of:}

Ali SH, Foreman J, Tozan Y, Capasso A, Jones AM, DiClemente RJ. Trends and predictors of COVID-19 information sources and their relationship with knowledge and beliefs related to the pandemic: nationwide cross-sectional study. JMIR Public Health Surveill 2020;6(4)::21071

Picone M, Inoue S, DeFelice C, Naujokas MF, Sinrod J, Cruz VA, Stapleton J, Sinrod E, Diebel SE, Wassman J, Robert E. Social listening as a rapid approach to collecting and analyzing COVID-19 symptoms and disease natural histories reported by large numbers of individuals. Popul Health Manag 2020;23(5):350-60

Pobiruchin $M$, Zowalla R, Wiesner M. Temporal and location variations, and link categories for the dissemination of COVID-19-related information on Twitter during the SARS-CoV-2 outbreak in Europe: Infoveillance study. J Med Internet Res 2020;22(8):e19629

Predictions, Pivots, and a Pandemic: a Review of 2020's Top Translational Bioinformatics Publications

Section 9: Clinical Research Informatics

Survey M. Christofidou, N. Lea, P. Coorevits

A Literature Review on the GDPR, COVID-19 and the Ethical Considerations of Data Protection During a Time of Crisis

Synopsis C. Daniel, A. Bellamine, D. Kalra

Key Contributions in Clinical Research Informatics

Best Paper Selection Content summaries of:

Bell SK, Delbanco T, Elmore JG, Fitzgerald PS, Fossa A, Harcourt K, Leveille SG, Payne TH, Stametz RA, Walker J, DesRoches CM. Frequency and types of patient-reported errors in electronic health record ambulatory care notes. JAMA Netw Open 2020 Jun 1;3(6):e205867

Estiri H, Strasser ZH, Murphy SN. High-throughput phenotyping with temporal sequences. J Am Med Inform Assoc 2021 Mar 18;28(4):772-81

Geva A, Stedman JP, Manzi SF, Lin C, Savova GK, Avillach P, Mandl KD. Adverse drug event presentation and tracking (ADEPT): semiautomated, high throughput pharmacovigilance using real-world data. JAMIA Open 2020 Oct;3(3):413-21

Zhang Z, Yan C, Mesa DA, Sun J, Malin BA. Ensuring electronic medical record simulation through better training, modeling, and evaluation. J Am Med Inform Assoc 2020 Jan 1;27(1):99-108

\section{1}


Section 10: Natural Language Processing

Survey E. Laparra, A. Mascio, S. Velupillai, T. Miller

A Review of Recent Work in Transfer Learning and Domain Adaptation for Natural Language

Processing of Electronic Health Records

Working Group Contribution

\section{Balkányi, L. Lukács, R. Cornet}

Investigating the Scientific 'Infodemic' Phenomenon Related to the COVID-19 Pandemic

Synopsis N. Grabar, C. Grouin

Year 2020 (with COVID): Observation of Scientific Literature on Clinical Natural Language Processing

Best Paper Selection

\section{Content summaries of:}

Jin Q, Tan C, Chen M, Liu X, Huang S. Predicting clinical trial results by implicit evidence integration. Proc of Empirical Methods in NLP; 2020

Poerner N, Waltinger U, Schütze H. Inexpensive domain adaptation of pre-trained language models: case studies on biomedical NER and Covid-19 QA. Proc of Empirical Methods in NLP; 2020

Ive J, Viani N, Kam J, Yin L, Verma S, Puntis S, Cardinal R, Roberts A, Stewart R, Velupillai S. Generation and evaluation of artificial mental health records for Natural Language Processing. NPJ Digit Med 2020;3:69

Section 11: Public Health and Epidemiology Informatics

\section{Working Group Contributions}

E. M. Borycki, A. W. Kushniruk, R. Kletk1, V. Vimarlun3, Y. Senathirajah, Y. Quintana Enhancing Safety During a Pandemic Using Virtual Care Remote Monitoring Technologies and UML Modeling

P. Indraratna, U. Biswas, J. Yu, G. Schreier, S.-Y. Ooi, N. H. Lovell, S. J. Redmond

Synopsis G. Diallo, G. Bordea

Public Health and Epidemiology Informatics: Recent Research Trends

\section{Best Paper Selection Content summaries of:}

Zheng L, Wang 0, Hao S, Ye C, Liu M, Xia M, Sabo AL, Markovic L, Stearns F, Kanov L, Sylvester KL, Widen R, McElhinney DB, Zhang W, Liao J, Ling XB. Development of an early-warning system for high-risk patients for suicide attempt using deep learning and electronic health records. Transl Psychiatry 2020;10(1):72

Roope LSJ, Tonkin-Crine S, Herd N, Michie S, Pouwels KB, Castro-Sanchez E, Sallis A, Hopkins S, Robotham JV, Crook DW, Peto T, Peters M, Butler CC, Walker AS, Wordsworth S. Reducing expectations for antibiotics in primary care: a randomised experiment to test the response to fear-based messages about antimicrobial resistance. BMC Med 2020;18(1):110

Degeling C, Carter SM, van Oijen AM McAnulty J, Sintchenko V, Braunack-Mayer A, Yarwood T, Johnson J, Gilbert GL. Community perspectives on the benefits and risks of technologically enhanced communicable disease surveillance systems: a report on four community juries. BMC Med Ethics 2020;21(1):31 
Research \& Education G. Hripcsak, M. J. Schuemie, D. Madigan, P. B. Ryan, M. A. Suchard

Drawing Reproducible Conclusions from Observational Clinical Data with OHDSI

History of Medical Informatics

\section{A. Kulikowski}

Pandemics: Historically Slow "Learning Curve" Leading to Biomedical Informatics and Vaccine Breakthroughs

Information on IMIA Welcome to IMIA 302

Honorary Fellows 304

IMIA Member Societies 305

Institutional Members 306

Addresses of IMIA Member Societies 308

Information on IMIA Regions Information on APAMI (Asia Pacific Association for Medical Informatics) 319

Information on Helina (African Region) 326

Information on MENAHIA (Middle East and North African Association for Health Informatics) 328

Information on NAMI (North-American Medical Informatics) 335

Information on EFMI (European Federation For Medical Informatics) 340

$\begin{array}{lll}\text { Miscellaneous } & \text { Contributors } & 346\end{array}$

Reviewers 347

IMIA Yearbook Special Topics 348 